\title{
Social Media, Mediation and the Arab Revolutions
}

\author{
Miriyam Aouragh
}

\author{
Oxford University, Oxford, United Kingdom, miriyam.aouragh@orinst.ox.ac.uk
}

\begin{abstract}
This article discusses the socio-political implications of user-generated applications and platforms through the prism of the Arab revolutions. Popular postmodern conceptualisations such as (post-nation state) network societies, (postclass) immaterial economies and (horizontal) political resistance through multitudes requires rigorous reassessment in the aftermath of the events in the MENA. Although the revolutions have led to a resurgence of debates about the power of new media, such arguments (or rather assertions) are echoes of earlier suggestions related to peculiar fetishisations of ICT in general and social media in particular. The point of my critique is not to deny the social and political usefulness of new media but to examine the pros and cons of the internet. I tackle the juxtaposition of the internet and political activism through the Marxist concept Mediation and investigate how the social, political and cultural realms of capitalism (superstructure) are both conditioned by and react upon the political-economic base. This helps us to understand structural factors such as ICT ownership (political-economic decision making of social media); while deconstructing the effect of cultural hegemony disseminated through mass media. It also overcomes an unfortunate weakness of some "academic Marxism" (an overwhelming focus on theory) by anchoring the theoretical arguments in an anthropological approach
\end{abstract}

Keywords: Mediation, Base and Superstructure, 'Facebook Revolution', Middle East, Arab Revolutions

Acknowledgement: I would like to thank Jamie Pitman for helpful references to the 'immaterial labour' debate; Jonny Jones for comradely advice concerning the Marxist theory of value; the anonymous reviewers for their valuable comments; and Rob Jackson for proof-reading.

There is no doubt that the internet is an important medium since it offers ways to disseminate counter-hegemonic content and at times even allows new forms of political mobilization. By hook or by crook, activists must experiment with the internet to be effective. This online political engagement requires a critical analysis though. Politics in the Middle East and North Africa (MENA) often operates in the context of media censorship, police oppression, war or colonial-occupation. Especially in times of revolution many forms of online politics are rendered meaningless - unless organically related to offline street politics. The events shaking the region since 2011 have starkly demonstrated this. I wish to revisit these developments from a media, communication and (non-western) anthropological angle.

The Arab evolutions motivated a broad range of responses and provided a publicity niche resulting in facile analysis of the "Arab Spring" and a sense of "intellectual frustration" (Sabry 2012, 80). Sabry identifies four categories: Muteness (intellectual impotence); Stammering; Tele-Techno(the 'experts'); Subaltern (the activists themselves) (81). A quick overview of the work published in communication and media disciplines responding to the 'Arab Spring' shows two remarkable features: the sheer volume of material produced (dozens of academic publications in several special issues dedicated to the topic) ${ }^{1}$ and its lack of engagement with Marxist theory. The fact that recent years have seen a popular re-emergence of interest in Marxist critiques while Marxist theories are hardly engaged with in mainstream academia shows a widespread gap between established and new scholarship and probably an inherited prejudice regarding 'systemic' analyses. To be clear, this is also the case for anthropology (Graeber 2001). ${ }^{2}$. Part of the explanation lies in an existing confusion at the very core of Marxist academia, centred on the dependency of superstructure as I will discuss. The overall objective of this paper is to offer a critical conceptualisation of the Arab

${ }^{1}$ Special issues related to internet activism and/or Arab revolutions are for instance: International Journal of Communication ["The Arab Spring and the role of ICTs", Volume 5]; Communication Review [Volume 14]; Arab Media \& Society [Issue 14]; Middle East Journal of Culture and Communication [Volume 5]; Globalizations [Volume 9]. Cyber Orient ["The Net Worth of the Arab Spring", Autumn 2012); Journal of Communication [“Social Media and the Arab Spring”, Volume 62].

${ }^{2}$ This is most probably related to a more prevalent anti-Marxist reflex, especially in US academia, which, not unimportantly, dominates the international academic field. As discussed by Graeber, many anthropologists (at Western universities) avoided Marxist theories in their work since Marxists were often persecuted. Even after WW2 and height of the Cold war, when there was more intellectual space, Marxist anthropology was absent or dominated by an orthodox Marxist (evolutionary) scheme. There was a break in the 1960s when most anthropologists' understanding of their discipline underwent a transformation, engaging more with a type of scrutiny exposing the workings of a system of inequality and injustice. A Marxist anthropologists' critique of non-Western social orders was not because it was different (the kind of relativism that was for long dominant in anthropology) from his or her own, but largely to the degree that it was similar $(2001,24)$. 
revolutions through the prism of the internet. But revolutions cannot be studied through the prism of the internet: internet activism is here viewed through the prism of the revolutions, combining theory with ethnographic insights both from meetings I had with Egyptian activists in Cairo in August 2011 and their online testimonies. This will help to push back the narrow presumptions about the universality of digital experiences and, by constructing a grounded empiricism, contribute to existing critical explorations.

The theoretical and political proposition regarding the potentials of social media, which underlies this paper, rests on a radical critique of the liberal-capitalist internet-ecology. From this follows a rejection of technological reductionism (not in the least because such approaches distract from necessary material-political explanations) and an inclusion of the disempowering materiality of technology. Social movement theories (many also formative to internet studies) were popularised with the surge of anti-capitalist movements, yet in some cases became part of the problem. An understanding of Marx is crucial to grasp how political encounters mediated through cyberspace impact existing political dynamics. Marxist theories of literature and art provided inspiring vantage points for a radical approach to social media and political change. I have found particularly helpful Terry Eagleton's 1976 expose Marxism and Literary Criticism. Critical Marxist work in communication and cultural studies (e.g. Kellner 2004, Wayne 2003) further helped construct my arguments.

Eagleton (1976) considers literature to be shaped by the means of production and distribution. Therefore to be able to understand its implications requires an awareness of the historical conditions (iv) as well as the social composition of the authors (2). This evokes exactly the broader dialectic I am interested in exploring regarding social media. The (revolutionary) interconnected role of literature was originally outlined by Trotsky (1991) who nevertheless stressed that literary forms should have, and in fact do have, a high degree of autonomy. Eagleton $(1976,26)$ relates to this analysis by arguing that literature and art do not merely bend to ideology but evolve partly in accordance with its own internal pressures. For instance, books are not just (structured) expressions of meaning but also commodities produced by publishers and sold for profit. Literature is in fact considered the most highly mediated of social products and is also part of the economic base (60). The superstructure functions as an ideological organiser of the social class that owns the means of economic production. This double metaphor has suffered from distortion because the concept of the base (political-economy) is easily confused to mean 'essence' and superstructure (ideology/media) just an extraction thereof. The dialectics of art and literature provides an important framework for the study of the social-political implications of online media productions as I will argue. Some of the unhelpful economistic analyses notwithstanding, it is important to include this class focus.

The overall objective of this paper is to shed light on the complex online-offline dynamics shaping and preceding the current revolutionary transformations, and to step away from the void 'Facebook Revolutions' cheering. In the past years several scholars have produced critical work problematizing the oft-assumed relation between increasing democracy and internet technology (e.g. Doogan, Fenton, Fuchs, Haug, Kellner, Mejias, Sayer, Terranova) with whom I will engage in this paper. I will start by describing the Marxist concept of mediation, which offers a creative and very helpful tool to explore the pros and cons of the internet in revolutionary turmoil. Especially in internet studies where the subject of investigation is also a powerful economic sector and condition of capitalist production, it is crucial to critique the economic context. Mediation unveils this relation between base and superstructure. How internet-related re-conceptualisations have in due course redefined the very definition of activism and resistance shall be reviewed in the second section. I recognise that the internet is both a product of capitalist logics and simultaneously used to resist those logics. In the third section I therefore discuss ICT imperialism and the potential impacts of this on political activism. In the final part of this paper I set out to empirically deconstruct how political organising and internet technologies relate, avoiding the customary straw-man positions. In the background of these debates I take the centrality of the concept mediation because it allows me to engage with its dual nature and hermeneutical distinction. Social mediation is not impressed by 'nodes' alone, instead, it highlights the nexus of political hegemony and liberation of internet politics. Although I proceed in a more integrated manner in the second half of the paper, the theoretical (sometimes dreary) propositions about base-superstructure deserve to be spelled out first.

\section{Deconstructing Mediation}

The aforementioned reluctance to engage with Marx (and more general confusions) is probably due to the fact that while 'base' represents a combination of forces and relations of production, one of the elements in this combination is 'more basic' than the other. As Engels himself anticipated 'If therefore somebody twists this into the statement that the economic element is the only determin- 
ing one, he transforms it into a meaningless abstract and absurd phrase" (in Eagleton 1976, 9). The confusion about the legal and political 'superstructure' mostly arises from the definition of the 'base'. An important correction given by Harman (1986) is that Marx doesn't make a single distinction between 'base' and 'superstructure' because there are two distinctions; between the 'forces of production' and the relations of production; and between the relations of production and the remaining social relations. The forces of production are dynamic and can come into conflict with the (more static) relations of production. The relations of production correspond to the forces of production - hence, as Harman lucidly argues, the forces of production (that have the agency and motivation) rebel against the relations of production - not the other way round.

So, to recap, the forces and organisation of labour are the economic structures (base) of society from which emerge a certain polity and politics (superstructure), and these in turn merge in different ways, depending on the historical situation in which it occurs. If as Marx and Engels argued, the class which is the ruling material force of society is at the same time its ruling intellectual force, how does this dynamic occur in the realm of ideology - literature, art, media? As hinted at above, the business and the production of ideas are interrelated. For instance, literary works or art are (and aren't) embedded in state ideology which is why the mediation between these forms requires an analysis in itself. They are forms of perception related to the dominant (state) ideology (Eagleton 1976, 7). Mediation suggests the presence of normative representations of social relations, but it also depends on what form of mediation (books, newspapers, films, websites) is at stake. Each technological transformation is both a continuation and a unique transformation, manifested in ways depending on a particular development. Every new technological force will also have implications for the balance of forces and the tools required. This is where the Marxist roots (base and superstructure) of mediation are most clearly related to the internet's political (e.g. expressing an ideology that prefers non-violent horizontal networks) - economy (a medium deeply embedded in neoliberal ICT corporations).

The revolutionary transformations that occurred in the availability and usage of communication and information technologies had enormous political implications throughout history. For instance, replacing the time-consuming technique of parchment with papyrus had important consequences for European Protestantism and via the upcoming bourgeoisie for other social classes too (Deibert 1997). Presenting phenomena as unprecedented occurrences with the adjective 'new' does not relate to how everyday technologies have morphed with each new stage of development (Briggs and Burke 2005). The popularity of blogs that shaped the Arab public sphere since 2006 is a good example. Armbrust (2007) and Ulrich (2009) remind us of the need to historicise technological (user-generated) developments such as Arab blogging by looking at the longer existing and strong culture of oral mediation, or tape-recorded sermons distributions and of course popular magazines. There is a common tension between historical continuity and change. But historicising is not merely tracing technical forces in themselves; in a Marxist epistemology what matters more is the place they occupy within a whole mode of production (Eagleton 1976, 74). Also, and therefore, the transformation or morphing does not occur immediately. According to Peters $(2009,18)$, most mass media passed through five stages: the technical invention (which is a combination of the old and new); cultural invention (thus how they are linked to new social uses); legal regulation; economic distribution; and finally, social mainstream ${ }^{3}$. But again, superstructure also refers to non-material (non-economic) consequences. Producers of 'culture' (in whatever form or expression) are relatively free, yet influenced by that material reality ${ }^{4}$. How this relation is structured, the interdependence formed, is called mediation.

There have been interesting discussions of the mediation of culture and communication in the Arab revolutions, such as Sabry's reference to the aesthetics and poetics of mediation $(2012,82)$. Rather than its literal meaning, this paper engages with mediation beyond the connotations of dissemination and signifies the capitalist rules of engagement between base and superstructure. Mediation reveals these inner relationships and lays down the patterns that obscure relations of exploitation; by doing so it represents both hegemonic and counter-hegemonic processes. The question is how to apply this Marxist exercise in the context of media technologies.

Wayne $(2003,128)$ identifies seven levels of mediation with regards to the media: text; production process; production context; industrial context; the state; modes of development; and mode of production. All these levels are related but the most important levels in the context of social media

\footnotetext{
${ }^{3}$ To the fifth phase can be added the register of ways new technologic inventions are countered, as is sometimes the case with dystopian deliberation about the internet, including by leftist progressives.

${ }^{4}$ As Harman clarifies, ideology and consciousness is "a subjective link between objective processes"; ideas develop on the basis of material reality and feed back into that reality. Thus while they cannot be reduced to that reality, they can neither be divorced from it.
} 
(Facebook, Twitter) are those addressing the production process and production of context. But the relationship between producer and consumer is itself contained in the practices of communication. ${ }^{5}$ Raymond Williams (1979), following Adorno's Theses on the Sociology of Art, stressed that mediation is in the object itself. This could correspond to what is believed to be the core characteristic of internet media. So how can we reconcile this apparent contradiction of mediation? For Marx, capitalism is a system that creates its own gravediggers. Besides a more organized fashion of exploitation the concentration of workers into workplaces, paradoxically, created the possibility of class consciousness and stronger ties through firmer constructions of identities that are in addition to existing identity formations based on shared expectations, endurances, lifestyles, and proximity. Nonetheless, the absence of (free, accessible) communication technology (through the free-market privatisation of these means) weakens the social ties of the exploited classes. But what happens to the process of mediation when this gap is overcome in terms of 'authorship', when the usergenerated content or products as well as the users' intentions are about free and artistic development, about social change and (internet) subversive activism? What happens to this process when even the producer and consumer are the same, the most celebrated feature of Web 2.0?

The (power of the) author as producer is not a new idea and is discussed by Marxist media theorist Walter Benjamin in 1934, later coined by Toffler (1980) as prosumer, and recently by Bruns (2010) produsage. But unlike the recent understandings focussing on participation by consumers within the capitalist system, ${ }^{6}$ Benjamin meant a revolutionary intervention to counter the dominant bourgeois media and ideology. It was even less about the participation of prosumers in corporations to further reduce investment costs and increase clientele as Fuchs $(2009,95)$ argues with regards to Facebook. Such a 'prosumer' doesn't signify democratization (participation) but rather a further commodification of human creativity.

My point is that ideological mediation is played out partly through the commodification of media sources and tools. Presently this occurs with corporate platform operators and providers who basically sell its users to advertisers and further intensify exposure to the commodity propaganda of advertisements while online (Fuchs 2012,146). This is the arena where the mediated base and superstructure is demonstrated most clearly in the case of the Arab revolutions: the available ICT is a direct output of corporate structure and ideological (consensual) symbols that have helped frame the narrative about social media and the Arab revolutions. But can we really draw such conclusions about very different media environments - Web 0 (before-internet) and Web 2.0 ? It seems that this has been the underlying understanding about the ramifications of neoliberalism and simultaneously the transition towards it and an information-economy. Consequently, mediation also has to be understood differently. It is important to engage with this critique for the sake of empiricism; but when we have the most accurate picture we also find clues for how best to fight (or how not). Thus, before I continue to discuss the internet in the Arab revolutions this has to be explained.

\subsection{From Das Kapital and class to Das Empire and Multitude?}

It is true that since the Communist Manifesto or Das Kapital there have been important developments, it could be argued that the dominant corporate media has restructured itself and morphed into different mode of production and capital. Perhaps technological innovations represent a new stage in society. A popular way to deal with this is focussing on what distinguishes interneteconomies in the new state contexts (from a post-war liberal welfare to a neo-liberal state). For many internet theorists, communication is the force of change. According to Castells (2009) communication is the central power (and counter-power) in contemporary society. ${ }^{7}$ Base can now be understood through informationalism, alluding to a technological development rather than mode of production. This adaptation is similar to what became known, in a more crude fashion, as immaterial labour by Hardt and Negri. They consider the ('immaterial') production of ideas (characterising this type of capitalism) by virtue of what it produces rather than the labour process. The internet is often seen as the qualitatively different commodity here, apparently confusing the term 'labour' with 'work'. According to Camfield (2007) the central theme in these analyses can't actually play the role assigned to it because they don't address how surplus value is extracted and tends to underestimate the exploitation that underlies it. A 'post-capitalist' economics in which the separation between consumption and production mysteriously dissolves with new technologies (consumer and producer became one) suggests that the internet can function outside the structures of capitalism,

\footnotetext{
${ }^{5}$ Williams engages here with Adorno's Theses on the Sociology of Art.

${ }^{6}$ For a helpful overview of the so-called 'democratic turn' and its introduction in the Knowledge Economy debate see Daniel Araya's review:<http://www.danielaraya.com/docs/Prosumerlnnovation.pdf>.

${ }^{7}$ Castells identifies four kinds of power: networking; network; networked and network-making power.
} 
turning class into a different category altogether. ${ }^{8}$ Meanwhile, in their work Empire Hardt and Negri understand immaterial labour as industrial production that has been 'informationalised' and which has therefore transformed "the production process itself." Manufacturing is regarded more as a 'service' which they then consider to be the driving force behind "the postmodernisation of the global economy" $(2000,293)$. The global economy is somehow one entity, beyond inter-state competition (perhaps the most important feature of modern capitalism), thus beside class (multitude) there is also a different role reserved for state (empire).

Ironically, while Hardt and Negri challenge his theory of value, Marx gives serious consideration to the social implications of technological development. He actually mentions that technology has the potential to unlock the free development of individualities and the reduction of labour time to a minimum in the service of artistic and scientific development (i.e. rather than for the sheer creation of surplus labour). ${ }^{9}$ To postmodern thinkers the (old) term 'labour' challenges the question of (new) 'knowledge production'. But for Marx labour represents action that both presupposes and propagates new knowledge. Far from ignoring the impact of the 'superstructure' on the 'base', as many critics have claimed for more than a century, Marx builds his whole account of human history around it. Political and ideological struggles that arise as a result of competition and exploitation, are decisive for whether a new rising class (based on new forces of production) displaces an old ruling class (Harman 1986). For Marx, knowledge and physical labour have always been continuous with one another but the idea of the informationalisation of industrial production is problematic.

Perspectives about a new capitalism are associated with a restructuring of the labour market and globalization causing a fusion of transnational market systems and new technologies, the supposed 'dematerialisation' of the economy (Haug 2009). 'Old' forms of employment are replaced by new internet-formed discourses that aligned it mostly with knowledge ('cognitive') processes. It is now "biopolitical production" in which the economic, the political, and the cultural increasingly overlap (Sayers 2007, 444). These, rather far-fetching, (re)definitions do not have a clear analysis of the exploitative mechanisms at work and have provoked critique such as describing these novel projections as coming down to 'the presence of left wing harmonies in the neoliberal chorus' (Doogan 2010, 29). Part of the motivation for this stems from the opinion that Marx left us illequipped to deal with the absorption of knowledge and new technologies in the production process, thus substituting the 'classical' Marxist tradition with 'immaterial labour'. It seemed that the analysis was flipped, because the challenge is to have a clear understanding of the social relations underpinning capitalist production "rather than fetishize its effects" (Fine \& Saad-Filho 2010, 23). But for Hardt and Negri $(2004,140)$ history moves on and social reality changes, thus old theories are no longer adequate: new realities demand new theories.

Conversely, technology is an integral fixture in Marx's analysis of capitalist society as the previous paragraph describes. Marx obviously did not delve into a communication and information medium at the time, but he didn't overlook its role either. Discussing technology as an alienating force of modern industry in Capital, Marx considers technology disclosing the process of production and thereby also "lays bare the mode of formation of his social relations, and of the mental conceptions that flow from them" ${ }^{10}$ From this we can understand that the relations of production rely on the production of property and information. Taking this further, the dual condition outlined here with the internet turns it into a much more lucrative techno-communication product as well as a usergenerated medium. Besides catering for its users, social media also constitute the mechanism that strongly underlies capital accumulation (Fuchs 2009). This, unsurprisingly, draws a different picture, and impacts how resistance is organised and, hence, needs to be assessed in relation to social movements as well before I can apply the related concepts to concrete empirical examples.

\section{How the Internet Redefines Resistance}

Celebratory portrayals of the Arab revolutions made possible with (Western) technology are not completely new. With the struggle of the Zapatistas; ${ }^{11}$ the revitalization of anti-capitalist protest movements (e.g. WTO-Seattle, World Social Forum); and new open-source platforms like

\footnotetext{
${ }^{8}$ Voluntarism in the blogger, open-source and hacker communities often comes to mind. A telling example is the recent case by former contributors against the much hailed Huffington Post. These bloggers had produced and helped disseminate Huffington content for free. It was the kind of immaterial labour praised indeed. But when the owner made a multi-million deal with AOL the philanthropy ended: they sued her and demanded a share in the proceeds. See: <http://www.politico.com/blogs/onmedia/0411/Unpaid_bloggers_sue_Huffington_Post_and_AOL.html>.

${ }^{9}$ These views can be found particularly in chapter 14 of the Grundrisse (Marx 1857/1858)

${ }^{10}$ From Capital Vol. 1, the rest of the paragraph in:<http://www.marxists.org/archive/lenin/works/1914/granat/ch02.htm>.

${ }^{11}$ Ironically, the Zapatistas have been appropriated in the original internet-resistance myth - they were not internet activists, but guerrillas in the mountains of Chiapas who deployed the internet to literally mediate their offline resistance.
} 
Indymedia, academic interest in communication and technology joined these waves. This enthused debates about the internet as the new spaces of resistance and a turn of politics into the realm of social networking sites developed considerably. But the more mediating the message of protest came to be considered the protest itself, it also introduced a commoditization of internet politics. To a certain extent this is true since communicating our demands and alternative analyses is fundamental. We want to construct (influence) meaning-making processes; we understand very well that the media are amongst the most fundamental spaces to achieve this on a broad scale.

Social movement literature is often based on theories of collective action. The prominence of the internet questioned the relevance of traditional collective action paradigms, (traditional) theories that emerged in conditions lacking the key communication possibilities presently available (or rather, for almost two decades by now). Then, does this imply that certain (pre)conditions are no longer universally present in the realm of activism? The much cited work by Bimber et al. (2005) argues that "new forms of collective action reliant on certain technological aspects illuminate several fundamental aspects of all collective actions that so far have remained theoretically obscure" (366). ${ }^{12}$ The two most important changes challenge the binary choices of participation (in the past this is assumed to rely on strong ties and vanguards) and the role of organisation (conceived mainly as vertical structures of command and control) with explicit leadership and division of labour. Bimber et al. reframe collective action as "a set of communication processes involving the crossing of boundaries between private and public life" (367). It is true that with the internet (especially Web 2.0) weak ties can be included and in effect contribute to political organising; it is not stuck between being a 'free rider' or a 'vanguard'. There is a false dichotomy however, joined by what seems to be an error in the overall assessment. Firstly there is a dichotomy between weak and strong ties, as if not anymore reliant on a constant weighing between cost and benefit, beneath its optimistic narrative there is a rather pessimistic outlook whereby motivation or political engagement is strongly dependent on 'low investment'. There will probably be an efficiency balance at stake but it obviously misses factors like solidarity, camaraderie, unity and of course necessity. My second point has to do with the word 'reliant' in the previous quotation; causing much of the confusion. The answer to the riddle can be found in this 'relative' condition as I will explain regarding the unequal effects of internet activism.

However, the authors consider the largest obstacle to be the nature of organisation (369). Here too Seattle (anti-WTO protests of 1999) seems to have shattered everything with its loosely coupled networks without a fixed structure of leadership and decision making or recruitment policies. Despite the high-dosage of mythology there are two underlying premises I take issue with: everybody everywhere seems to be connected (otherwise it wouldn't be a democratic -representativeform of organising obviously); it seems that people value online commitment and community similarly as offline [physical] interaction. Illustrative is the following quote they cite "Right now, every time we do an action, we send out an e-mail and a hundred people show up. It's like magic. We couldn't do it without e-mail" (Bullert 2000, 4; in Bimber 2005, 370). But anyone who was or is involved in activism knows that it isn't magic. When you mobilize and send out an email, that is communicating, such as calling, texting, fly-posting and standing on a soap box was, and often still is. I don't think we consider the turn-out in these cases as magical, moreover: not everyone is connected. Perhaps more relevant in the context of this paper: many people are not convinced enough to sacrifice their time, risk their jobs or accept bodily harm based on a passing message received via online platforms.

Technology has undercut some of the annoying requirements of organising and allows a broader circle of people (to be semi/activists) to contribute and it is important to accept that there is improvement. But many of the examples have to do with dissemination (thanks to email, bulletin boards, SNS) and better ways of sharing, as Bimber et al. rightfully argue (372). But how does the mobilization of new collective action now result from "largely uncoordinated efforts" (373)? What is missing is the content and how the demands come about: who organised the initial or eventual calls/meetings/protests? There is some truth to Bimber's suggestion but it is only partial. If there are, hypothetically, six crucial stages or spheres of political organising then the issue of coordination of dissemination covers two at most. Thus as activists we are relieved from some important burdens but most characteristics of political organising are not overcome or altered because they have to do with the power relations we depend on and the privilege we (because of our subversion) don't possess and wish to actually remove altogether. Nevertheless, as the authors note "new faces of collective action exhibit both formalized and informal structures" (374). And, if the boundary crossing phenomena "lie at the heart of new forms of technology based collective action, and they form the general class of which the traditional free-riding decision is one special albeit very im-

\footnotetext{
${ }^{12}$ The authors discuss some of the prominent collective action theories since Olson's 1965 study marked this discipline.
} 
portant, subset" (377), how are we to asses this reframing if it turns out not to be so since it underestimated previous and non-wired dynamics? Some of the same processes are found in nontechnological spaces of interaction - which makes it so important to historicise our current modes of communication and embed these analyses in ethnographic realities. For instance, the networks of the baqqal (neighbourhood grocer), the taxi driver, the mosque or hammam (public bath) includes an enormous amount of information flows. All of a sudden it seems less extraordinarily unique that boundaries between private and public domains can be crossed. But this is not a sufficient analysis, in the last section I will return to when exactly what matters in more detail.

The problem is that revisions of concepts (such as resistance and revolution) in a time during which the real-life practices behind those very concepts are defied, results in a flattening of the concept of resistance and potentially in turn a weakening of this very resistance. These redefinitions are not autonomous but closely associated to the altered meaning of class (considered to be defeated) and state (dissolved into flows of networks) by neoliberal globalisation; even the replacing of political-economy (Kellner 2002, 287). The techno-tunes stemming from these theoretical alterations actually resemble earlier ('post-colonial') shifts which contributed to analytical moves from politics to culture. Paradoxically, the subaltern-type reassessments, de-politicised the debate in the long term (removing some of the necessary conceptual tools), particularly in the context of the Middle East which comprises neo-colonialism and imperialism. ${ }^{13} \mathrm{New}$ social movement paradigms turned to the possibility of creating new identities, equating 'old' only with struggles over access to resources and identities based on class alliances, the (original) idea of collective identities and class struggle were deemed outdated, conservative or essentialist. The internet as representational activism (texts, visuals, online public spheres) sits comfortably with and change at the level of representation and social movement theories that related to narrative or discursive practices - exercising power in and through discourses - further flattening the concept of resistance. The theoretical shifts coincide with novel interpretations about the role of new online networking methods for political change because the internet offers democratised networks and the increasing power of the individual. ${ }^{14}$

Consequently, if labour and capital are both core forces in capitalism, the state is the mediator between (the exploitation of) the first and (the potential of) the second, the state is the metaphorical hyphen in political-economy. The main (Eurocentric) flaw here regards the recommendation to 'go beyond' the nation-state to those struggling for economic and territorial autonomy or (in the case of Palestine or Western-Sahara) a state even. As noted, mediation is not about representation in a merely figurative sense; it is that political and economic regulation through corresponding state structures and ensuing ideologies. Gramsci developed the concept hegemony as used earlier by Lenin to suggest that capitalism maintained control not just through violence and political and economic coercion, but through a hegemonic culture in which the values of the bourgeoisie became the 'common sense' (hegemony). Ordinary people identify with the bourgeoisie (consensus culture) and maintain the status quo. With this understanding of hegemony Gramsci set out to emphasize the importance of the superstructure in both maintaining and fracturing relations of the base. ${ }^{15}$

The internet is not non-hierarchical but embedded in structural inequalities and the strong privileges of some (existing) media over others. Besides neoliberalism and the fact that information flows are not in the same league as those dominant on the internet (O'Neil 2009, 15), the problem is that other forces of power set the rules for such fights. There is the strong effect of hegemony (of coercion and consent) in capitalist ideology, disseminated and shaped by state-institutes. This relates to the meaning of mediation as a de-fetishizing force; most directly to unveil the impact of social media. Mejias (2011) noted that the overwhelming prominence of the narrative that Facebook and Twitter are crucial agents for change (besides being conceptually wrong) white-washes corporate capitalism.

Right from the start, debates about the internet coincided with the 'globalisation discourse' because, indeed: neo-liberal globalisation had strongly shaped conventional modes of communication (Featherstone and Lash 1995). They were accompanied by exciting stories about the internet creating gender equality, increasing economic development and other anticipations, but also doom-

\footnotetext{
${ }^{13}$ In such anti-class definitions marginal comes to mean 'the other', I don't want to simply end with a 'Third World' view and thus acknowledge that the same accounts for the 'First World'. To follow Eagleton: "The true scandal of the present is that almost everyone in it is banished to the margins" $(2004,19)$.

${ }^{14}$ Often mentioned are the four versions of power according to Castells: Networking power; Network power, Networked power, and Network-making power. Castells is important to mention as he has had a great impact. He is the 5th most cited author and is susceptible for unintended re-conceptualised frameworks that continue to be associated to him.

${ }^{15}$ For a collection of analyses see: <http://www.marxists.org/archive/gramsci/index.htm>, and see also International Socialism Journal (114, Special Issue on Gramsci):<http://www.isj.org.uk/index.php4?s=contents\&issue=114.
} 
scenarios about virtual reality; often articulated with postmodern theory. Take for instance this view by Baudrillard (from Impossible Exchange):

Reality is growing increasingly technical and efficient; everything that can be done is being done, though without any longer meaning anything. [...] As for the sign, it is passing into the pure speculation and simulation of the virtual world, the world of the total screen, where the same uncertainty hovers over the real and 'virtual reality' once they go their separate ways. The real no longer has any force as sign, and signs no longer have any force of meaning (Baudrillard 2001, 5)

Some new technologies were indeed revolutionary in the realm of everyday life (to refuse this new reality is basically to refuse progress). But it is precisely therefore in the penetration of daily life that they involve new modes of fetishism: help disseminate capitalist norms (Kellner 2002, 299). Insofar as social and economic relations are not egalitarian within society today, we need to expect the same for the economy of new media (Mansell 2004, 97). The political realities after $9 / 11$ and the collapse of the housing market and subsequently the banking system itself in 2008 forcibly 'corrected' some of the premature propositions about the political impact of the internet downgrading the significance of nation-states in (temporarily) global networks. This is for instance tackled by Jones $(2011,89-90)$, who argued that the importance of class presents itself in two ways: the class nature of the internet (as a sector) which conditions our communication styles (open source FLOSS entrepreneurialism notwithstanding) and class in terms of the organisational consequences of the proponents of internet media (as opposed to independent left-wing publications sold face-to-face on streets and protests) which has real implications for political organising. The latter is important because, as Mejias (2010) argues, network theories rely heavily on being wired by technologically connected nodes, but the overwhelming majority are not, they are 'para-node'. Through this critique Mejias shows the politics of inclusion and exclusion encoded in the network as they are embedded in global economic systems based on corporate interests. Most people in revolutions are nonnodes, excluded from the networks, those who have no access to technologically mediated networks of communication. Technology is one of many societal interactions. There are nodes in all networks. What matters is to differentiate between the quality of technological networks and social networks, and between each and when these two interact (Fuchs 2009, 96). But they can be organically interacted through mediators, as I will explain.

What do Marxist theories, then, actually contribute to my understanding of contemporary revolutionary activity and ICT? As I argued at the outset of this paper, reconciling differences between theories that start from social structure (top down) and individual motivation (bottom up) comes down to unveiling the mediation without ending up disregarding individual human action. This is not a new problem in social theory. Engaging with the theory of value is not common in anthropology because this discipline was wedged in the theoretical limbo of social theory at large (Graeber 2001, $2)^{16}$. Eventually the very idea of applying grand theory was seen as a contradiction since an anthropologist's place is in (the other's) ethnography. But ethnography always applies a theory since it is based on a ray of assumptions, the real choice is thinking about this epistemological challenge explicitly or disregarding it (Graeber 2001, 20). Marxist anthropology offered the opportunity to add a critical niche when it started to be more centred around the idea of 'mode of production', a focus that offered debates beyond (the classic anthropological) exchange but how societies continue to exist and "reproduces" itself. The questions are often about how a society's most basic forms of exploitation and inequality are rooted in the social relations through which people do so (24). These Marxist-inspired inquires introduced a series of powerful analytical terms - exploitation, fetishism, appropriation. Marxism has not had an enormous impact on anthropology in an institutional sense but its influence was apparent (e.g. "critical theory"), and inspired a whole series of new approaches (25). The main motivation was to unmask the hidden structures of power, dominance, and exploitation that lay below even the most mundane aspects of daily life. But critical theory ended up "sabotaging its own best intentions, making power and domination so fundamental to the very nature of social reality that it became impossible to imagine a world without it" (30). In that case, criticism loses its point altogether. Contemporaries like Baudrillard basically argued, that resistance is futile since we are stuck in a totalising system. A good example is this élan, following-up from the previous reference:

\footnotetext{
${ }^{16}$ The Marxist theory of value considers that the value of commodities is derived from the human labour that went into producing them, but this fact tends to be obscured when the object is bought and sold on the market so it seems that its value arises naturally, from the qualities of the object itself. This can also be considered the trap in the reinterpretation of internet commodities.
} 
[T] he economic sphere, the sphere of all exchange, taken overall, cannot be exchanged for anything. There is no metaeconomic equivalent of the economy anywhere, nothing to exchange it for as such, nothing with which to redeem it in another world. It is, in a sense, insolvent, and in any event insoluble to a global intelligence. [...] Politics is laden with signs and meanings, but seen from the outside it has none. It has nothing to justify it at a universal level (all attempts to ground politics at a metaphysical or philosophical level have failed). It absorbs everything which comes into its ambit and converts it into its own substance, but it is not able to convert itself into - or be reflected in - a higher reality which would give it meaning (Baudrillard 2001, 3-4).

According to Graeber (2001) this mix of abstract yet edgy discourse explains the appeal of mass consumption as a topic of upper-middle class academics. But he also reminds us that these awkward preoccupations did not occur in a vacuum but respond to the dissolution of the vast social movements in the '60s; the rise of neoliberal ideologies; itself partly made possible by the failure of the left to come up with plausible alternatives (30). The most influential impact on anthropologists' understanding of value came from Appadurai's "Commodities and the Politics of Value" (1986). Anthropologists would do better, he suggests, to forget Marx's approach (which has an emphasis on production in which value arises from human labour; thus essentially a capitalist phenomenon) and look instead to value that is not rooted in human labour or a social system but arising from exchange, from individual desire. Unlike Marx's, his model can easily be applied even where formal markets don't exist; there is always some form of exchange after all. This approach has its advantages: it allows the analyst to skip past the problem of social totalities (structures of meaning) and focus on individual actors and their motivations (Graeber 2001, 30-31). But the other side of the coin is that it leaves us with a doomed and static image of commerce (self-interested, acquisitive calculation) as a universal human urge (33). It is not very surprising how this comes to fit with the emphasis on power and consumption in critical theory.

But there is also a critical realist philosophy of a different kind made popular by Bhaskar, which merges a Marxist theory of ideology that defends the critical emancipatory inquiry against postmodernist analyses. One that sees reality operating at different levels, what is happening at the surface does not tell us all, underneath that surface will be strains in and between structures that have a potentiality to destabilise existing social relations. What this approach suggest is that human agency is made possible by social structures that themselves are conditioned, but we are capable of consciously reflecting upon (changing) the actions that produce them (Bhaskar and Callinicos 2003). As Harman (2007), commented though, these notions are not new discoveries; Marx pointed out (in volume III of Capital) "All science would be superfluous if the outward appearance was the essence of things"; Lukács stressed the distinction between different levels of reality in History and Class Consciousness and Gramsci described Marxism as "the philosophy of practice".

This dialectical method inspired me to separate between social media as space and tool (Figure 1). I partly derive this distinction from the above correlation between practice and theory, an important tradition in Marxist social theory. My dual assessment echoes this twin agency-structure approach. Internet space refers to both the structural aspects of the internet and society, while internet tool represents the tactical aspects and political agency. Having made this deconstruction, it still requires a critical inclusion of the materiality of the internet as it actually exists, such as in terms of internet access (Alexander and Aouragh 2011). Actual penetration rates and other statistical evidence are important arguments against the celebratory and technophile claims cheerleading neoliberalism, but I argue that online and offline politics are actually unequal. A misunderstanding regarding the negative interpretations of the internet (shared also by progressive critics) is caused by the fact that the total penetration rates are not representative. We cannot assess the political impact of the internet in terms of 'the population' and should, instead, appreciate this (especially the 'tool' function) in terms of its meaning for 'the activists'. To start with, this allows me to get deeper into the matter and give affirmative assumptions where they are the case. I will further explain this in the final section.

We need more than the increase of communication and dissemination. I take from internet theorist Fenton (2006) that first and foremost political solidarity is the socio-political glue, and that social movements gain public legitimacy and political force through the embodiment of solidarity offline. I conclude that without an organised body with a centre, resistance is more likely to dissipate. The misconception of revolutionary organising comes down to centralism $=$ hierarchy $=$ authoritarianism. A Leninist understanding of democratic centralism therefore has two conditions: it has to be democratic because only through democracy can the best lessons be incorporated and the most advanced experiences internalised and if necessary generalised. But, secondly, consensus-style activism without centralism will look very liberal (and morally superior) yet it is largely unpractical. It is legitimate to disagree, to not reach consensus, it is a method that can at times allow for a certain 
trial and error in our tactics and in turn improve (or disprove) the overall methods of struggle. A more relevant problem with these approaches is the lack of democratic structures and as such accountability - what Freeman called the tyranny of structurelessness. Resistance in Gramsci's dialectical understanding of power and hegemony is the independent organised class (through a revolutionary party) which acts not as a substitute but represents the organised body of the oppressed. But perhaps more to the point in the case of the Middle East: forms and choices of organizing are not autonomous but very determined by the territorial context and the balance of power therein. While the discourse (and to some extent practical manifestations) of capitalism and imperialism changed, its effects did not (Callinicos 2009). There are changes in the economic practice in a globalized era; but it is not as if nation-states don't network (or float) for instance. The question is where exactly power lies in those 'spaces' and 'flows', Global political-economy, ICT and Middle East politics are more related than one thinks.

\section{ICT Imperialism}

Not that long ago, the myth was that ICT positively impacts promotion of freedom because the expansion of ICT generates the tools and services enabling citizen participation in the decisionmaking process, and thus democracy. Political-economy, which in the MENA region often comes down to colonialism and imperialism, is the elephant in the room in much of the ICT analyses. But there was a peculiar anticipation that the internet would increase 'development' (ICT4D) in the MENA. This is no surprise because the ICT sector was the front runner of a shift in the MENA from state to liberal [privatised] economy, with a more or less correlated experience of democratization processes and social political reform in the late 1990s. Jordan and Egypt were hailed as the poster boys of this new experience. Whereas development, deployed as rhetorical tools to promote the internet, is often understood to entail economic prosperity and even peace, the very imperialism that obstructs the actual justice and prosperity in the MENA are hardly mentioned by ICT policy propagandists.

Ya'u (2004) referred to the merging of political-economy and ICT as the 'New imperialism' because global economic participation depends on ICT. It is the life-line of neoliberal globalization. The WTO allows the flow of market intelligence for greater profit margins, and thus if we zoom out we can see that enforced institutionalised policies like the Free Trade Agreement (FTA) increased rather than prevented digital divides. But the most important feature of this imperialism, control and ownership, is very prevalent through what is called 'global governance' directed by big powerful institutes that strongly privilege industrialised free market states. This consolidation can only occur through state support, to be precise.

The infrastructures of the internet expose how powerful and centralised bodies like the Internet Corporation for Assigned Names and Numbers (ICANN) are, demonstrated by their allocating of URL names and addresses. Apparently, the argument is that the sheer volume of information will transform policies. But such analyses (e.g. Shirazi 2008) about the MENA are mostly derived from euro-centred analysis (e.g. Brinkerhoff 2005) claiming that the internet facilitates the expression of liberal values such as individualism, modernity. Weak ICT is related to the combined problem of 'late development' post-independence impediments itself stemming from colonial structures that were inherited. In essence these structures hardly changed and continued in a neo-colonial fashion (Murphy and Zweiry 2010). The internet is bounded by neoliberal rules of engagement which disadvantage Middle East countries (Saleh 2011). Ya'u thus makes an important contribution by reintroducing neo-colonialism and imperialism into our terminology. While the agenda for the 2003 WSIS conference in Tunisia was set by the private sector, in that case the Internet Telecom Union (ITU), which serves powerful conglomerates, had the official goal of promoting ICT as a bridge to digital divides. As Costanza-Chock $(2003,4-5)$ shows, civil society and NGO actors were invited to such summits to mask the neoliberal agenda and also refer to this corporate behaviour as 'imperialist'. Of course there is another definition of imperialism which is not sufficiently clear and cannot be solely explained through parasitical ICT firms.

The Middle East is predominantly depicted as suffering from political social conflicts. While these conflicts are mostly portrayed as an essential characteristic, they are rarely identified as a result of external factors (occupation of territory by Israel or invasions under the banner 'war on terror',

\footnotetext{
${ }^{17}$ To be fair, Castells does strongly argue that power is unequally distributed because capitalist corporations are more dominant. He also points at the dialectical relation between the online 'space of flows' and the offline 'space of places'. It is important to relate critically yet precisely here. A similar reinterpretation occurred in parts of the neo social movement theory. To Melucci's dismay, the 'new' in his original writings became reified as a category and meant as opposing class with collective action, presenting a false contradiction between supporters of the old and new movement theories (Melucci 1996:6).
} 
the arming and funding of dictatorships). As Terranova (2004) argues, rather than being disconnected from a particular place (virtual reality) internet power is grounded. The precondition for internet activism should at least be affordable availability and infrastructural access and reach. This is a far cry from space-less and border-less myths and the very point of struggle over selfdetermination and territorial autonomy. This is not to mention a massive amount of personal data that has become accessible to both corporate and state institutions (Lyon 2003), especially with the advent of the war on terror and Web 2.0 (Fuchs 2011). The overwhelming materiality of power over technology in capitalist nation states - a power structure itself (that hyphened demarcation in political-economy) was practiced during the internet shut-down in Egypt at the start of the revolution. Showing us just how 'free' the free market is Vodafone almost immediately complied with government orders to disconnect its paying clients. The provider Noor was the last one to operate but that was mainly because it hosted the stock exchange. Discussing the fascinating graphs offered by Renesys (listing all the ISPs and visualising their active connection line until the day of the shutdown when all of a sudden there is a flat line), Dan Mcquillan argues that the 'falling of the internet' shows a sequenced-pattern (with short intervals) suggesting that the companies were being phoned one at a time and being told to take their connection off the air. ${ }^{18}$ With this, we are also reminded that it is real people, with agency - managers and CEO's - and with choices and decision-making power running the show. And this, at the end of the day, also implicates them as collaborators. Looking back, it seems quite extraordinary that internet connection was restored at the moment the fiercest fights and state-orchestrated crackdown (battle of the camels) took place, but this also suggests there were plenty of internal divisions at the heart of the regime. That chaos can be explained by the fact the security apparatus was taken by surprise by people's well-organised and fierce resistance.

Imperialism is not just like any other label for Middle East politics but lies at the centre of its oppression and resistance. This is a region where the most important natural resources for capitalism (oil, gas, phosphate) are found and its geography practically determines the trade routes (including access to those very resources). On top of this: the region is an important source for the (statesponsored) arms industry. In light of these realities the copy and paste colour revolutions become more about Western liberal uprisings than about indigenous experiences. The unprecedented uprisings (termed the Arab spring by the western media but revolutions by the activists) are driven by popular protest and were linked to years of preparations (Marfleet and Al-Mahdi 2009).

\section{The Arab Revolutions and Internet}

Up until the Egyptian and Tunisian revolutionary uprisings, the thought of collective selfemancipation through classical revolutionary processes were deemed a part of the past. Revolutions are "first of all a history of the forcible entrance of the masses into the realm of rulership over their own destiny" (Trotsky 1930). The Arab revolutions refute many of the social theories that considered revolution a thing of the past (Callinicos 2011,5). The uprisings renewed the very idea of revolution and showed world-wide resonances through protest movements that centred on city squares such as the Spanish Indignado Movement and the Occupy Movement which started in Wall Street, New York, and spread to 900 cities. Initial assessments seemed confused by the discovery that they too use new technologies and assumed that the internet caused the "tipping point". Conversely, before the 2011 Arab revolutions (and before the 2009 protests in Iran - Twitter Revolution), foreign-policy and security experts were interested in the use of the internet in the Middle East with regards to counter-terrorism and online radicalisation. These essentialist approaches neglect other important developments; the surprised response to the revolutions unmasked this bias. The tipping-point momentum in revolutions is not really related to the tools at hand but to political-class dynamics. Revolutions are unique, there are decades where nothing happens; and suddenly there are weeks where decades happen, to paraphrase Lenin ${ }^{19}$. Revolutions offer us an important material understanding of the implications of the internet. The events open up a space for bottom-up analysis that has previously been ignored.

Between 2005-2009 Ukraine's Orange Revolution, Lebanon's Cedar Revolution, Moldova's Twitter-Spring and Iran's Green-Twitter Revolution were a preview of the popular copy and pasting that were to emanate in the prominent 2011 markers of events in which the internet was elevated as a crucial player. The Arab Spring/Facebook reference revolutions were simultaneously a contin-

\footnotetext{
${ }^{18}$ The 'flat-line' graphs by Renesys are found in this online post:< http://www.renesys.com/blog/2011/01/egypt-leavesthe-internet.shtml>.

${ }^{19}$ It is not clear where this quote is from but it is found in a 1920 text by Lenin and bundled in his Collected Works available online: <http://www.marxists.org/archive/lenin/works/1920/oct/20.htm>.
} 
uation and a break of this narrative. When the struggles intensified, 'revolution' began to mean something else than the copy-and-paste demarcations and fetishized with colourful flora and fauna labels. Overt fascination with social media gave the impression that the revolutions were mainly middle class and secular. ${ }^{20}$ Western experiences were taken as the model or Arab revolutions evaluated through the lens of modernity going hand in hand with the idea that social media plays an important role in developing a sense of modernity or, as this fascinating analysis claims: "Much like Western societies, parts of Egyptian society are transforming away from traditional groups and towards more loosely structured "networked individualism" (Wellman et al. 2011, 6). The underlying assumption of the modernity-technology paradigm is that digital politics changed 'traditional' methods of political organising. With the rapid nature of mass communication platforms and new forms of organising, discipline became non-hierarchical. In such a digital world, it is assumed that ideologically 'recalcitrant' groups such as the Muslim Brotherhood are no longer the only (or effective) way to organize political opposition. In this narrative, the Muslim brotherhood was not seen as legitimate or modern (as opposed to digital) while certain individuals (e.g. Google rep. Wael Ghonim, who was also the secret administrator of the much-discussed Khaled Said Facebook group) were admired; projecting a certain wishful thinking about a new social media generated non-ideological (secular) generation. But this means that Western liberal values are being injected into what are predominantly local ideals and above all efforts. A similar orientalist representation follows from interpreting and, as a result, discussing the 'local' as a single entity.

I don't wish to replace a negative with a positive essentialism, as the initial outburst of the "Facebook Revolution" commentary tended to do, but to consider the internet as tactically embedded in a broader political strategy. The revolutions raise crucial questions about the role of communication technology in social movements, such as how political agency is mediated in and through cyberspace. While the preferred 'network' claims less hierarchy and more autonomy, the complex local political context refutes the approach to political activism hidden within these narratives. The revolutions represented an ideological melange of progressive socialists, liberal Islamists, capitalists, reactionary conservatives; but 'ideological' groups such as the active Revolutionary Socialists and huge Muslim Brotherhood were at the base of the revolution. Also, the reality of imperialism has several implications, one of them being the active policy of protecting brutal dictators, a fact that many of those protesting did not forget, and a reminder of one of the causes for the on-going revolutions. Ben Ali and Mubarak were both Western backed rulers and the initial response of the West can best be described as a complicit hesitance. Only when it became clear that the mass protests were indeed historical events with crucial (geo-political) ramifications did the political statements change. The needles of the political compass in Washington-London-Paris reversed; hesitance was swapped for support.

Two of the most important factors of the on-going revolution are the changing political landscape with an amalgam of new leftist political parties emerging and, secondly, the re-surfacing of class struggle signified by the largest workers strikes and struggles since 1946 and the formation of independent unions. Class relations are a crucial element of the political struggle in Egypt. Rosa Luxemburg (1970) theorised how political uprisings crystallize in a periodic fertilisation: with the spreading of the political struggle the economic struggle extends. But, and this is the digital difference, a third segment of the political dynamic is the manifold political campaigns and coalitions born on Tahrir square. Many here use and work within online and offline networks as will be discussed in the next section. I assume that this positive standpoint coincides with the massive coverage, because it was a celebration of the tools rather than the causes.

The local specificities are crucial because the internet is shaped by a strong relation with the ground. Online activism facilitates offline liberation strategies. In other words, explaining the value of the internet can never make sense without including a political and historic contextualisation. Rather than a sudden 'awakening', the region was already in turmoil, protests had been accumulating for almost a decade, starting with the outbreak of the Second Intifada and Ariel Sharon's massacre of Palestinians; the invasion of Iraq; anger over leaders seen as the local lackeys of the US and Israel. A widespread and deep anger over the regional politics overlapped with domestic issues and grew deeper as the economic impact of the neoliberal (IMF/WB) privatisation combined with the price increases caused by the global financial crisis. Wikileaks documents in 2010 that the extent of corruption and Arab collaboration were not a cause but a confirmation - and thus a deepening - of the growing anger.

In the face of these important and contentious events technology was of essential importance, probably projecting the everyday conditions of the authors of those narratives, rather than thinking

${ }^{20}$ This coincides with geo-political double standards: it doesn't matter what Palestinians, supporters of Hezbollah or Ahmedinejad do with social media. 
through the everyday Arab political realities. Inserting the internet corporations-Facebook, Twitter, Google - at the centre of analyses suggests that certain western characteristics were crucial, denying a genuinely popular Arab revolution. Fundamentally, this is a form of orientalism. Orientalism as a discourse relies on presenting and representing the MENA and her people with a set of (colonial) wishes and interests. Moreover, Edward Said 1979 Orientalism shows that an orientalist discourse also lays down the rules of representation. In due course (when unchallenged/resisted) this will become so subtle (normalized) that it does not even have to rely on prejudicial (chauvinistic) views. The production of knowledge through certain technophile mediation is important here because technology symbolises modernity which in turn symbolises western civilisation. But it does not have to necessarily or explicitly be organised as such: it is also part of the dominant (hegemonic) notions internalised about the region and the role of the internet. This is nowhere as intense as in Middle East studies, the very foundation of this discipline is itself intimately connected to foreign policy (Mitchells 2003). The revolutions show that this myth is still present today as my critique of the connection between technology, modernity and revolutions illustrates. The fallacy in much of the (media) discourse is where the internet equals a new youthful generation of activists. This framing prefers non-violence and the non-ideological as the better form, thereby insinuating a negative undertone for resistance that includes all forms (violent-non-violent, manifest-latent) of struggle.

Internet activists rely on the same tools as their oppressive authorities, they also have to juggle between self-activity and the potential of being co-opted in these new dynamics; the potential subversion of power is not very great in the face of the extreme asymmetrical relation. Youmans and York $(2012,3)$ remind us that social media platforms were not designed to cater to activists in the first place; there is a direct mismatch between the commercial logic and activist use of social media as public information infrastructures. Information system policies empower authoritarian regimes concretively in the prohibition of anonymity. This arises from its design and governance concerns, which hamper the activists on two levels: the application of certain code programming and user terms (intellectual property, content) (idem, 12$)$. Fuchs $(2009,99)$ simplifies the matter by asking to what degree are users autonomous if 19 out of the top 20 Web 2.0 platforms are profit-oriented, the only exception being Wikipedia. Returning to the (base and superstructure) dialectics of the concept mediation, I assume that while the (user-generated) internet affects the material conditions it also implicates political activism.

\subsection{Online-Offline Dialectics}

Discussing the role of the internet, it is important to distinguish what effect we mean to address. How does the internet tip the scales of power? Castells (2009) identifies three important advances for social movements that simplify this complex enquiry: flexibility, scalability, survivability (respectively: reconfiguration, expanding/shrinking, and operational continuation). Of particular interest for the context of the Arab revolutions are the ideas of scalability (the expanding of ties) and survival (operational continuity). The cut-off created a survival mode at its most extreme, therefore also many pre-digital technologies were crucial (such as dial-up modems and fax-to-web bridges), creating so-called analogue networks ${ }^{21}$. I merge these operationalisations with the assessment that the internet has two sides, it is a tool for activists (survival, operational continuity) and a space for activism (expanding networks). Archiving, technological solidarity (cooperation) and political conviction proved to be meaningful elements of counter-hegemonic organising as this section will show.

I deconstruct the theoretical (abstract) level of interrogation by (re)connecting the (hermeneutic/ethnographic) features of online politics. I suggest interpreting the online/offline divide as a reflection of the base-superstructure separation and the space/tool separation as part of the overall political strategies and tactics also prevalent in mediation. Previous fieldwork in Palestine and Lebanon suggests that the stage (or timing) of certain actions has more relevance for the potential role of the internet. I thus distinguish between various revolutionary stages: pre-revolution (preparation and mobilization), moment of revolution (the actual tipping points), and post-revolution (successful continuation or dangerous escalation). This dialectics of mediation, illustrated in the Matrix of internet resistance (figure 1), shows clearly that the internet is not dominant but can be a factor of change. Merging these conceptual deconstructions, results in a much more coherent understanding of internet resistance.

\footnotetext{
${ }^{21}$ Internet Artizans, 10 Februari 2011:<http://www.internetartizans.co.uk/socnets_with_old_tech_egypt\#comment-8423>
} 
Matrix of Resistance (Analytical Framework)

\begin{tabular}{|c|c|c|c|}
\hline \multirow{4}{*}{ 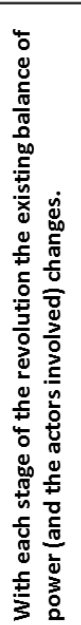 } & ${ }_{\text {Stage }}{ }^{\text {Space }}$ & Online & Offline \\
\hline & $\begin{array}{c}\text { Pre-Revolution } \\
\text { (Preparation \& Mobilization) }\end{array}$ & Space & Space \\
\hline & $\begin{array}{l}\text { Revolution } \\
\text { (Tipping Point) }\end{array}$ & Space & Space \\
\hline & $\begin{array}{c}\text { Post-Revolution } \\
\text { (Continuation \& Escalation) }\end{array}$ & Space & Space \\
\hline
\end{tabular}

Figure 1: Matrix of Internet Resistance

Political networks and collective protest are, first and foremost, consolidated offline. But online spaces of interaction and communication amplify political agendas and opinions. Social media are the choice of most Arab activists simply because they are the spaces and tools which (predominantly young) people already choose for everyday communication. And thus for a specific layer of activists and participants in the uprisings internet spaces served a crucial function as counterhegemonic spaces (Warner 2002). In the pre-revolutionary period a collective critique of the existing political and social order were articulated on many such spaces, without this preparatory stage the maturation of the tipping point is hard to imagine. Adding a hermeneutic separation based on phases is also significant to appreciate the different values of technologies during the chaotic outbreak of revolt. For instance, on the $25^{\text {th }}$ of January it was critical to use real-time online updates in order to device the safest routes for marches or locate the most risky one's and avoid those. Kira Allmann shows the life and death significance of a functioning mobile technology in her research among activists in Cairo (2012). And during the revolution the internet was relevant as a vehicle for building global solidarity. The internet also became a parallel space for political identity formation: where people met other people who relate to their opposition and shared information about protests, or disseminate messages that further ignited their anger and determination. In this sense, social media platforms become online public spheres convenient for political deliberation and a space where opinions are shaped and at times (when offline opportunities are severely compromised such as with curfews) decisions are made.

Within the social networking spaces of the Shabaab 6 April (April-6 Youth) and Kuluna Khaled Said (We are all Khaled Said) Facebook groups (the English and the Arabic one), as well as those of high-profile individuals (Alaa Abdel Fatta, 3arabawi, Sandmonkey). These were not only meeting points for activists themselves, they were also the source of much of the forwarded mobile text messages and emails, Tweets and shared Facebook posts and as such instrumental in mobilizing a section of the wired-youth. In a revolutionary phase repetition is important, and so is agitation (for a march towards Tahrir) or the consolidation of general political analysis (the need to stay in Tahrir square) and the organization thereof. These engaging acts echo the trio-characteristic of revolutionary political organising: Educate-Agitate-Organize. Those involved in these online realms are a selective segment of the protesters - and social movements are in themselves a selective portion of society. In extraordinary times, the impact of these sub-scenes can reach beyond their usual networks marking the digital-revolutionary difference. In revolutionary moments, when at a 'tipping point', emotional/cognitive power is crucial. This corresponds to how Castells (2009) in the aforementioned 'advances' deconstructs the public impact of internet power as framing, agenda setting, indexing. Without the innumerable video files provided via Facebook and YouTube by ordinary people, the revolutions would not have been documented (and therefore: experienced) with the same intensity. Massive reporting by conventional sources has political repercussions, such as giving activists the confidence to advance their agendas through the capacity of mediation to reassure people that they are not alone and thus influencing the judgements and choices of activists. 
I referred to the relative importance, to counter the difference between absolute and proportional representation, which is often forgotten. One of the other signs of the relative importance of ICT was the particular empirical dynamic as related by activists in Cairo. There were interesting divisions of labour between techno-savvy activists, crackers and hackers; those able to communicate in different languages; those with well-established international networks; those who can reach large local audiences (unions, football supporter clubs, and student movements). Activists very consciously use different tools for different audiences. Two tents on Tahrir Square were manned by techno-savvy protesters with their laptops and tapping power from lamp posts while signs on the tent announced the point to gather videos and pictures; mobile phone footage recorded during the blackout was collected and posted online so as to be used by journalists. Those activists not in Egypt would follow tweets from within Egypt, translate and re-tweet (RT) to non-Arabic speakers, and offer online critiques of misrepresentations.

I intentionally mention social media as parallel spaces and as disproportionate because the internet is valued less than where/when one can meet face-to-face, such as the overlapping privatepublic places in the previous section signify. With regards to previous discussions about resistance and the importance of democratic centralism it is important to explicitly state that those physical meetings are better for political planning and organising and building trust; for conscripting personal sacrifice as the hundreds of martyrs testify. Another reason is that offline protest sites were those usually connected to mosques in densely populated working-class neighbourhoods, and university campuses. The fact that the revolution continued despite the internet black-out is of monumental importance.

During a visit in August 2011 several activists recalled how they experienced the revolutionary upheavals in the early days (January/February). For Mohamed, Salma and Dina, being cut off didn't dismantle the revolt; the disruption of the mobile phone services was far more crucial for on the ground politics. The crucial tactics that finally led to the occupation of Tahrir Square had little to do with Facebook, in fact: false information was purposely posted to confuse the mokhabarat (secret security). For weeks activists had met daily, often in a cramped living room, and it is precisely because the organising was done offline that it was rarely noted by the internet-obsessed reporters. Also, while the technology was absent the people, and their physical resistance, were very present. Paradoxically, it reduced distraction and gave focus during the five-day blackout. Social networking sites like Facebook are not a social network but a social-networking-tool. Its users, together with all those non-connected, those outside the virtual structures of the 'nodes' what Mejias (2010) called the para-nodal, were network. Thus not the technological networks but the people were the backbone. According to well-known blogger and revolutionary socialist, Hossam alHamalawi, the real strength of the internet occurs most dramatically when mainstream media begin to use their data as sources of information and voices as witness accounts. Such was the case with live-feeds in January and February. Re-dissemination from big and highly respected mediums such as Al Jazeera, added to the fame of these tools, which at the same time reminds of the indirect mediation.

The MENA region at large has the world's highest internet penetration growth rates (1600 per cent for 2001-2009) in terms of internet usage; particularly the increase of social (user-generated) media in 2011 are indicative (ASMR 2011). But instead of isolating 'the internet', I see a new creation of synergies. Consider for instance how social networking and satellite broadcasters interacted when Al Jazeera became a megaphone for activists in Tunisia and Egypt when it aired their YouTube content. The internet is not crucial but important to organise and archive the bravery and resolve and these recorded events are valuable for other activists (Naguib 2011, 17). The real empowering impacts can be found in this nexus.

With the verbally-graphic narratives of Sandmonkey I give a slice of the (start of the) revolution as it unfolded. Whereas archiving is important in itself, with digital media this happens so easily and real-time updates are quickly buried under millions of other updates - the same day. The revolution of Egypt was beamed to millions via the now world-famous Kuluna Khaled Said Facebook groups, Twitter and YouTube. This digital footprint, straight from the epicentre of events, as documented in his words since the call for protest on January 25, 2011, have been archived on Twitter. The Twitter voices included activists who were very prominent in the physical movements ${ }^{22}$.

There are several caveats about the prospects of the internet as a space or tool of activism. Firstly, there is an increasing balance between hegemonic and counter-hegemonic users, as demonstrated in the previous section about ICT and imperialism. Another important prospect is that activists in the online social media space are operating in an online community that increasingly mirrors their own. The implication of a digital world filtered by social-networking sites (dominated by

\footnotetext{
${ }^{22}$ These are selections of Tweets which were recited by Nunns and Idle (2011) in their joyful Tweets from Tahrir.
} 
the parasitical Facebook) that create unrepresentative bubbles is a result of these platforms derived from corporate premises and marketing algorithms. The consequences will reach wider than pure economics, including new rules of mobilization: debating, sharing and inviting those already largely on your side and actually not reaching out to wider networks. Pariser (2011) argues that with the rise of personalization (e.g. Google and Facebook customizing search results) internet users are sent down particular information tunnels and hence controlling-and limiting-the information we consume based on the motivation to predict what users are most likely to click, threatening the autonomy of how we consume or share information. Therefore, I argue that it is the very awareness of these techno-social power fields, as outlined in this article that will become increasingly crucial. This social capital has 'real' offline repercussions for activists-the difference between being arrested, and intercepted online by being lured into believing a certain narrative.

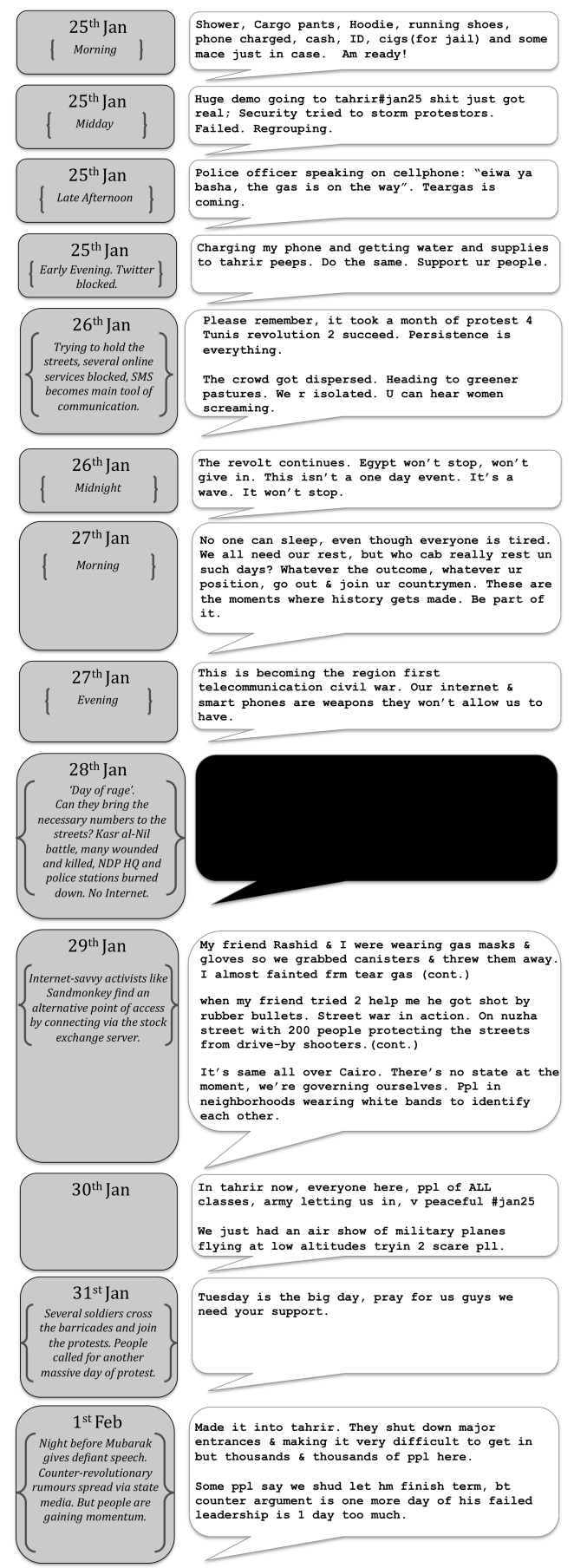

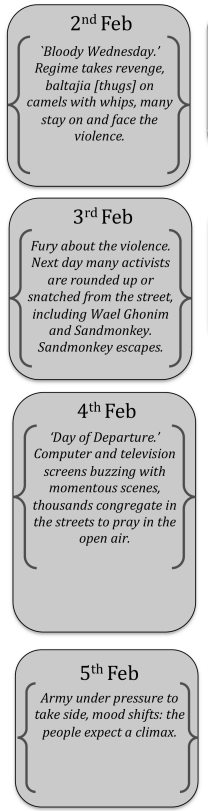

$8^{\text {th }} \mathrm{Feb}$
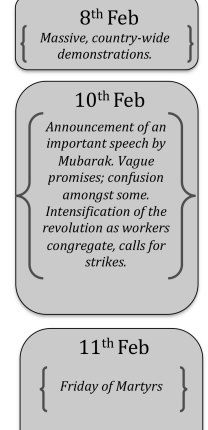

Please don't think people will stop if the army joins sides $w /$ the president. We are just hoping
the situation resolves without blood. This will be our greatest division yet. I hope the people will remain united no matter what. did it. I wanna cry from happiness.

To everyone who ridiculed us, opposed us, wanted us to compromise, i say: YOU ARE WELCOME:) TODAY
WE ALL CELERRATE!!!

Now let's remove his fuckin name from

Noverything. I don't wanna hear the from
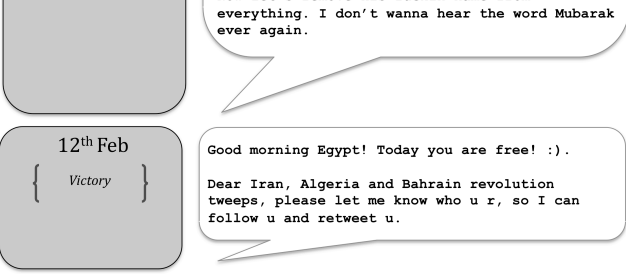

Good morning Egypt! Today you are free! :).

Dear Iran, Algeria and Bahrain revolution
tweeps, please let me know who $u x$, so I can
follow

Figure 2: Narrating the Revolution through Twitter by Sandmonkey. ${ }^{23}$

\footnotetext{
${ }^{23}$ Graph-design made with help of Kira Allmann, Oxford University.
} 


\section{Conclusion}

The ultimate and recurring question for many of us is the following: would this have happened without the internet? One of the answers is that it would not have been exactly the same, i.e. we wouldn't be able to RT and forward the amazing updates of people like Sandmonkey, or the YouTube footage from the ground and in response to many such mediations assemble at the Egyptian, Tunisian, Libyan embassies in protest of the complicity of our governments and in support and celebration with the people rising up. Revolutionaries could not have countered many of the government lies as they came out. This is the most visible part of social media as mediation. This matters greatly for the concrete labours of web-designers or Twitter authors and must be viewed as being interlocked and mutually constitutive; both are engaged in creating use and surplus-value. Marx envisioned technology becoming a means to liberation, provided it is freed from the tyranny of capital. To Marx a writer is also a productive labourer not in so far as he produces ideas, but in so far as he enriches the publisher who publishes his work. ${ }^{24}$ When immaterial labour is valorised it makes us blind to these impediments. Immaterial labour remains anchored in class relations and the attempt to by-pass that fails to grasp the devastating economic crisis and the revolutionary turmoil currently taking place.

Another answer could be that, of course, the revolution would have happened because the main conditions were there anyway, maybe it would not have been January but February or 80 days not 18 for Mubarak to be defeated. But the real answer is that we need to apply a dialectical and historical materialist approach to the whole question: thus this is an illogical question to begin with, like asking whether without printed leaflets earlier revolutions could happen. This is the stage we are at in the production and development of technology and it is a medium in the conditions we have not ourselves chosen.

I discussed the internet as a tool of protest in the Arab revolutions as part of larger politicaleconomic landscape in which political activists operate; they allude to an (orientalist) framing and reflect the deeper ideological meaning of the Marxist concept of mediation. I evoked the interplay between technology and Marxist politics and invoked examples from Arab activists. This multilevelled investigation allows me to go beyond the dominant Eurocentric focus that prevails in (mainstream) internet studies. I argued, echoing Rosa Luxemburg, that revolutionary change does not rely on spontaneous unorganized acts: it needs organizers, leaders, determination, and accountability. Discipline and structured organizing enables activists to generalize from complex and uneven realities and they are imperative for the survival of political movements. The activist networks do not confirm the view of leaderless swarms as often remarked when 'new' internet structures for political activism are concerned. It is mostly because it looked like it was a new, youth, non-ideological, online, horizontal movement that it gained attention and perhaps for many disillusioned with mainstream politics to give it the benefit of the doubt. Invoking the notion of mediation made us understand that clichés about the role of the internet don't help us understand the dual character of the internet: it empowers and disempowers. How to describe the relationship between art as production and art as ideology is one of the most important questions because it connects modes of production to representation, this in turn is important because "unless we can relate past literature, however indirectly, to the struggle of men and women against exploitation, we shall not fully understand our own present and so [will be] less able to change it effectively" (Eagleton 1976, 76). This paper therefore offered a conceptual understanding of internet activism that integrates imperialism and political-economy with the possible value and contribution of the internet to grassroots social capital. Social media cannot be reduced to capital ideology but have a rather particular relationship to it, revealing to us the limits of that ideology too (19). This is not a contradiction at all but the normalized exception in the ultimate rule called 'capitalism', a paradox prominent in the opening of Marx and Engels' Communist Manifesto for a good reason.

\section{References}

Allmann, Kira C. 2012. Mind, Body and Phone: Mobility, Mobile Technology and Political Activism in the Context of the Egyptian Revolution. (Unpublished Master's Thesis). University of Oxford, Oxford, United Kingdom.

Aouragh, Miritan 2012. Framing the Arab Revolutions: Myth Meets Modernity. Cinema Journal (51) 4.

Aouragh, Miriyam and Anne Alexander. 2011. Sense and Nonsense of Facebook Revolutions. International Journal of Communication 5: 1344-1358.

Aouragh, Miriyam 2008. Virtual Intifada: Online Activism and everyday Resistance. Journal of Arab and Muslim Media Research 1 (2): 109-130.

${ }^{24}$ Theories of Surplus Value is available online:<http://www.marxists.org/archive/marx/works/1863/theories-surplusvalue/ch04.htm> 
Arab Social Media Report (ASMR). Vol. 1 (2). 2011. Civil Movements: The Impact of Facebook and Twitter. Accessed May 25, 2012. http://www.dsg.ae/NEWSANDEVENTS/UpcomingEvents/ASMRHome.aspx.

Armbrust, Walter. 2007. New Media and Old Agendas: The Internet in the Middle East and Middle Eastern Studies. International Journal of Middle East Studies 39 (4): 531-533.

Bhaskar, Roy and Alex Callinicos. 2003. Marxism and Critical Realism: A Debate. Journal of Critical Realism (1(2).

Benjamin, Walter. 1970 (1934). The Author as Producer. Republished by New Left Review I/62 July-August. http://www2.warwick.ac.uk/fac/arts/theatre_s/postgraduate/maipr/teaching_1112/warwick/st2/kobialka_reading_-

benjamin_w_- the author_as producer.pdf

Briggs, Asa and Peter Burke. 2005. A Social History of Media From Gutenberg to the Internet. Cambridge: Polity Press.

Bruns, Axel. 2010. From Reader to Writer: Citizen Journalism as News Produsage. In International Handbook of Internet Research, edited by Jeremy Hunsinger, Lisbeth Klastrup, Matthew Allen, 119-134. Dordrecht, NL: Springer

Burgess, Jean and Joshua Green. 2009. YouTube: Online Video and Participatory Culture. Cambridge, MA: Polity Press.

Callinicos, Alex. 2001. Social Theory - A Historical Introduction. Cambridge: Polity

Camfield, David 2007. The Multitude and the Kangaroo: A Critique of Hardt and Negri's Theory of Immaterial Labour. Historical Materialism 15 (2): 21-52.

Callinicos, Alex. 2011. The Return of the Arab Revolution. International Socialism 130, April. Accessed May 25, 2012. http://www.isj.org.uk/?id=717

Castells, Manuel 2009. Communication Power. New York: Oxford University Press.

Carpenter, Charli and Daniel W. Drezner. 2010. International Relations 2.0: The Implications of New Media for an Old Profession. International Studies Perspectives 11 (3): 255-272.

Carey, James W. 2005. Historical Pragmatism and the Internet. New Media \& Society 7 (4): 443-455.

Costanza-Chock, Sasha. 2003. WSIS, the Neoliberal Agenda, and Counterproposals from 'Civil Society'. Journal of Communication Inquiry 3 (2): 118-139. Paper presented for OURmedia III, Barranquilla Conference May, 30 2003.see also: http://mediaresearchhub.ssrc.org/wsis-the-neoliberal-agenda-and-counterproposals-from-civil-society/resource view

Deibert, Ronald. 1997. Parchment, Printing, and Hypermedia: Communication in World Order Transformation. New York: Columbia University Press.

Doogan, Kevin. 2011. New Capitalism? The Transformation of Work. Cambridge, MA: Polity.

Eagleton, Terry. 1976. Marxism and Literary Criticism. Berkeley, CA: University of California Press.

Eagleton, Terry. 2004. After Theory. London: Penguin Books.

Eagleton, Terry. 2011. Why Marx was Right. United States: New Haven, CT: Yale University Press.

El-Ghobashy, Mona. 2011. The Praxis of the Egyptian Revolution. Middle East Research and Information Project 258. http://www.merip.org/mer/mer258/praxis-egyptian-revolution

El-Mahdi, Rabab, and Philip Marfleet, eds. 2009. Egypt: The Moment of Change. London: Zed Books.

Featherstone Mike and Scott Lash. 1995. Globalization, Modernity and the Spatialization of Social Theory: An Introduction. In Global Modernities, edited by Mike Featherstone, Scott Lash, and Roland Robertson, 1-24. London: Sage.

Fenton, Nathalie. 2006. Contesting Global Capital, New Media, Solidarity, and the Role of a Social Imaginary. In Reclaiming the Media. Communication Rights and Democratic Media Roles, edited by Bart Cammaerts and Nico Carpentier, 225242. Bristol: Intellect..

Fine, Ben and Alfredo Saad-Filho. 2010. Marx's Capital. $5^{\text {th }}$ ed. London: Pluto Press

Fuchs, Christian. 2009. Some Reflections on Manuel Castells' Book "Communication Power". tripleC - Open Access Journal for a Global Sustainable Information Society 7 (1): 94-108.

Fuchs, Christian. 2011. Cognitive Capitalism or Informational Capitalism? The Role of Class in the Information Economy. In Cognitive Capitalism, Education and Digital Labour, edited by Michael A. Peters and Ergin Bulut, 75-119. New York: Peter Lang

Fuchs, Christian 2012. The Political Economy of Privacy on Facebook. Television \& New Media 13 (2): 139-159.

Hardt, Michael and Antonio Negri. 2011. Arabs are Democracy's New Pioneers. The Guardian, 24 February.

Hardt, Michael and Antonio Negri. 2001. Empire. Cambridge, MA: Harvard University Press

Hardt, Michael and Antonio Negri. 2004. Multitude. War and Democracy in the Age of Empire. New York: Penguin Books

Harman, Christ. 1986. Base and Superstructure. International Socialism 2(32): 3-44.

Harman, Chris. 2007. Dialectics of Morality. International Socialism 113.

Haug, Wolfgang Fritz. 2009. Historical-Critical Dictionary of Marxism: Immaterial Labour. Historical Materialism 17 (4): 177185

Hirschkind, Charles 2011 Uprising in Egypt: The road to Tahrir. The Immanent Frame: blog of Social Science Research Council Blog: http://blogs.ssrc.org/tif/2011/02/09/the-road-to-tahrir

Howard, Philip N. 2010. The Digital Origins of Dictatorship and Democracy: Information Technology and Political Islam. Oxford: Oxford University Press.

Idle, Nadia and Nunns, Alex 2011. Tweets from Tahrir: Egypt's Revolution as it Unfolded, in the Words of the People Who Made It. London: Or Books.

Jones, Jonny. 2011. Social Media and Social Movements. International Socialism 130.

Kellner, Douglas. 2002. Theorizing Globalization. Sociological Theory 20 (3): 285-305.

Kellner, Douglas. 2004. Cultural Marxism and Cultural Studies. Accessed November 25, 2011. http://www.gseis.ucla.edu/faculty/kellner/essays/culturalmarxism.pdf

Kahn, Richard and Douglas Kellner. 2004. New Media and internet Activism: From the "Battle of Seattle" to Blogging. New Media \& Society 6 (1): 87-95.

Kahn, Richard and Douglas Kellner. 2005. Oppositional Politics and the Internet. Cultural Politics 1 (1): 75-100.

Mansell Robin. 2004. Political Economy, Power and New Media. New Media \& Society 6 (1): 96-105

Marfleet, Philip . 2011. Egypt Shaped at the Grass Roots. Open Democracy, 25 June. Online: http://www.opendemocracy.net/philip-marfleet/egypt-shaped-at-grass-roots

Marx, Karl. 1857/1858. Grundrisse. http://www.marxists.org/archive/marx/works/1857/grundrisse/ch14.htm

Mazarella, William T.S. 2007. The Myth of the Multitude, or, Who's Afraid of the Crow? Critical Inquiry 36: 697-727.

Mejias, Ulises. 2009. The Limits of Networks as Models for Organizing the Social. New Media \& Society 12 (4): $603-617$. 
Mejias, Ulises. 2011. The Twitter Revolution Must Die. http://blog.ulisesmejias.com/2011/01/30/the-twitter-revolution-mustdie

Mitchell, Timothy. 1988. Colonising Egypt. Cambridge: Cambridge University Press.

Mitchell, Timothy. 1991. America's Egypt: Discourse of the Development Industry. Middle East Report 169: 18-36.

Mitchell, Timothy. 2003. The Middle East in the Past and Future of Social Science. University of California International and Area Studies Digital Collection, MIT-IJMES (1).

Morozov, Evgeny. 2011. The Net Delusion. London: Allen Lane.

Naguib, Sameh. 2011. The Egyptian Revolution: A Political Analysis and Eyewitness Account. London: Bookmarks.

O'Neil, Mathieu. 2009. Cyber Chiefs: Autonomy and Authority in Online Tribes. London: Pluto Press.

Pariser, Eli. 2011. The Filter Bubble. What the Internet is Hiding From You. New York: Penguin Press.

Peters, B. 2009. And Lead Us Not into Thinking the New is New: A Bibliographic Case for New Media History. New Media \& Society 11 (1\&2): 13-30.

Sabry, Tarik. 2012. On Historicism, the Aporia of Time and the Arab Revolutions. Middle East Journal of Culture and Communication 5 (1): 80-85.

Saleh, Nivien. 2011. Third World Citizens and the Information Technology Revolution. Basingstoke: Palgrave Macmillan.

Sayers, Sean. 2007. The Concept of Labour: Marx and his Critics. Science \& Society 71 (4): 431-454.

Said, Edward W. 1997. Covering Islam: How the Media and the Experts Determine How We See the Rest of the World. New York: Vintage Books.

Shirky, C. and Malcolm Gladwell. 2011. From Innovation to Revolution. Do Social Media Make Protests Possible? Foreign Affairs (March/April).

Terranova, Tiziana. 2004. Network Culture: Politics for the Information Age. London: Pluto.

Toffler, Alvin. 1980. The Third Wave. New York: Bantam Books.

Trotsky, Leon. 1930. The History of the Russian Revolution. http://www.marxists.org/archive/trotsky/1930/hrr/ch00.htm

Trotsky, Leon. 1991. Literature and Revolution. London : Redwords.

Ulrich, Brian. 2009. Historicizing Arab Blogs: Reflections on the Transmission of Ideas and Information in Middle Eastern History. Arab Media \& Society 8, http://www.arabmediasociety.com/?article=711

Wayne, Mike 2003. Marxism and Media Studies: Key Concepts and Contemporary Trends. London: Pluto Press.

Warner, Michael. 2002. Publics and Counterpublics. Public Culture 14 (1): 49-90.

Wu, Tim 2011. The Master Switch. The Rise and Fall of Information Empires. New York: Alfred Knopf.

Ya'u, Yunusa Z. 2004. The New Imperialism and Africa in the Global Electronic Village. Review of African Political Economy 31 (99): 11-29.

Youmans, William and Jillian York. 2012. Social Media and the Activist Toolkit: User Agreements, Corporate Interests, and the Information Infrastructure of Modern Social Movements. Journal of Communication 62 (2): 315-329.

Zweiri, Mahjoob and Emma C. Murphy. 2011. The New Arab Media, Technology, Image and Perception. Reading: Ithaca Press.

Williams, Raymond. 1977. Marxism and Literature. Oxford: Oxford University Press.

\section{About the Author}

Miriyam Aouragh

Aouragh is associate member of the Middle East Centre (Oriental Institute), University of Oxford. She teaches Cyber Politics in the Middle East and her research concerns the everyday implications of the internet for activists as well as cyber warfare in the Arab-Israeli conflict. Her Palestine Online: Transnationalism, the Internet and the Construction of Identity came out in 2011 (IB Tauris). Miriyam is a socialist activist. 